\title{
Lanthanum Derivative from "Tara" Tannin for Steel Temporary Protection
}

\author{
Oriana D’Alessandro, ${ }^{\dagger, \S}$ Gonzalo J. Selmi, ${ }^{\S}$ Cecilia Deyá,*,+,§® Alejandro Di Sarli, ${ }^{\S}$ \\ and Roberto Romagnoli ${ }^{\dagger, \S}$ \\ ${ }^{\dagger}$ CONICET; Facultad de Ciencias Exactas, Universidad Nacional de La Plata, La Plata, Buenos Aires Argentina \\ ${ }^{\ddagger}$ CONICET; Facultad de Ingeniería, Universidad Nacional de La Plata, La Plata, Buenos Aires Argentina \\ ${ }^{\S}$ CIDEPINT-CICPBA-CONICET, Av. 52 e/121 y 122, La Plata, Buenos Aires Argentina
}

\section{Supporting Information}

\begin{abstract}
Tannins are extracted from certain plants and contain numerous phenol groups. They may be employed, together with their derivatives, to formulate protective coatings due to their inhibitive properties. The objective of this research was to synthesize lanthanum "tannates", to formulate washprimers. Two "Tara" (Caesalpinia spinosa) tannins and $0.1 \mathrm{M}$ $\mathrm{La}\left(\mathrm{NO}_{3}\right)_{3}$ were employed to obtain the corresponding tannates. The inhibitive action of the tannates was evaluated by linear polarization and corrosion potential measurements employing a SAE 1010 electrode. Lanthanum tannates were used to formulate wash-primers whose anticorrosion performance was evaluated by corrosion potential and ionic resistance measurements. The primers were incorporated in alkyd paint systems and their anticorrosion performance was tested in the salt spray chamber and by electrochemical impedance spectroscopy. Lanthanum tannate primers protected steel and behaved in a similar way to that formulated with zinc tetroxychromate.
\end{abstract}

\section{INTRODUCTION}

Metallic structures and machinery normally possess bare surfaces which need temporary anticorrosion protection prior to their use. In many cases, this temporary protection is required during the fabrication process. Finished metallic parts also need some kind of protection during shipping or storage in different atmospheres.

Many different temporary protective systems are described in the literature. ${ }^{1} \mathrm{~A}$ wash-primer is a multifunctional protective system which deposits a conversion coating onto the metal surface. ${ }^{2,3}$ It can be applied on steel, stainless steel, aluminum, galvanized steel, etc. to give a dry film whose thickness is comprised between 8 and $13 \mu \mathrm{m}$. The function of wash-primer is to passivate metallic surfaces to temporarily protect the metal and, finally, allow the application and adhesion of a full bodied primer; particularly in the case of those difficult-to-paint metals like aluminum or galvanized steel. Wash-primers are formulated with an inhibitive pigment, currently zinc tetroxychromate, and phosphoric acid to phosphatise the metal surface. However, chromates are questioned because their negative impact on the environment and on humans' health. ${ }^{4}$ The binder is polyvinylbutyral resin in a water and alcohol mixture.

Tannic acid and tannins may be considered as eco-friendly inhibitors which could replace chromates. Tannins are extracted from different parts (bark, root, leaves, and fruits) of certain plants and contain numerous phenol groups. The disposition of these phenolic groups in the molecule enables the complexation of metallic ions, especially iron ions to form iron "tannate" films thus converting the metal surface generating a protective film. ${ }^{5,6}$ This reaction is better accomplished in the presence of phosphoric acid. ${ }^{7-12}$ Tannins extracted from a great variety of trees were used to protect metals. The most employed ones were obtained from the following plants: mimosa, ${ }^{6,9,10}$ chestnut, ${ }^{7,12}$ pine, ${ }^{13}$ "quebracho", 14 mangrove, ${ }^{15,16}$ etc. New tannins are being proposed as a consequence of the reconnaissance and further exploitation of woods and forests continues. $^{17}$

Tannic acid was found to inhibit steel corrosion in acid media by the formation of an iron tannate film. Its inhibitory efficiency is higher than $89 \% .^{14,18}$

It was demonstrated that "Quebracho" (Schinopsis sp.) and "Mimosa" tannins are mixed inhibitors because they influence both reactions, the anodic and the cathodic ones. The inhibitive action of these tannins decreased as the $\mathrm{pH}$ increased. ${ }^{14,18}$

The protection of the metal surface by tannins is affected negatively by chlorides which turned the metal surface more

Received: August 10, 2017

Revised: February 7, 2018

Accepted: February 19, 2018

Published: February 19, 2018 
active. No passivity could be achieved when the chloride concentration is increased beyond $500 \mathrm{mg} \cdot \mathrm{m}^{-2} .19$

There is a great variety of commercial products which are claimed to stabilize and/or transform the surface oxide layer. As a trend, these products contain tannins but it was suggested that they did not possess the same anticorrosion behavior of a classical primer containing chromates. ${ }^{20}$ These products are designed to be applied on poorly prepared surface to transform the adherent oxide layer. The conversion layer was mainly composed of a magnetite whose stoichiometry differs from that normally found.

The employment of tannins in formulations to be applied on corroded metals did not lead to conclusive results; however, the authors found that they may improve the anticorrosion performance of the painting system as a whole. .,12,20,21 $^{2}$

Tannin derivatives, often called tannates, with proved anticorrosion efficiency, have been developed and employed in anticorrosion paints. The word "tannate" refers to any salt or ester of tannic acid. Giúdice et al. carried out pioneer investigations on the employment of metallic tannates in anticorrosion paints with promising results. ${ }^{22-24}$ More recently, the employment of zinc tannates with improved protective performance was reported. $^{25,26}$ These tannates were obtained employing "Tara” tannin. Zinc tannate obtained from Tara tannin seemed to be an effective antifouling pigment for marine coatings. ${ }^{27}$ Tara (Caesalpinia spinosa) is a small leguminous tree which is abundant in Peruvian territories and may be found distributed worldwide. Gallotannins are the main constituent of Tara tannins (53\%) and may be obtained from the plant extract by alkaline hydrolysis. ${ }^{28,29}$

The purpose of this investigation was to formulate an ecofriendly wash-primer containing lanthanum tannate (LT) instead of zinc tetroxychromate. This last pigment is toxic and carcinogenic, whereas the toxicity of LT is low. Lanthanum tannate may be considered as belonging to the so-called fourth generation of corrosion inhibitive pigments. This generation of pigments is constituted by hybrid organic/inorganic pigments which are the result of the combination of an organic compound with inorganic species. ${ }^{30}$ There is a great variety of organic compounds which may be employed to develop these type of inhibitors: surfactants, ${ }^{31}$ organic compounds like those with $\mathrm{O}, \mathrm{N}, \mathrm{S}, \mathrm{P}$, and/or $\pi$ electrons; ${ }^{31}$ carbohydrate polymers, ${ }^{32}$ plant extracts, ${ }^{30,32}$ etc. The most commonly employed inorganic species are zinc cation, ${ }^{30,33}$ lanthanide cations, ${ }^{34,35}$ sodium nitrite, ${ }^{36}$ potassium halides, ${ }^{37}$ etc.

LT was synthesized in the laboratory by treating a suspension of Tara tannin with lanthanum salts. Lanthanum compounds inhibit the cathodic reaction on different metals by the precipitation of the sparingly soluble hydroxide. ${ }^{38,39}$ The protective behavior of $\mathrm{LT}$ and that of the wash-primer containing this pigment were both evaluated by electrochemical techniques. In a second stage, the wash-primer was integrated in a complete coating scheme whose anticorrosion performance was assessed by electrochemical impedance spectroscopy (EIS) and accelerated tests (salt spray and humidity chambers). It was shown that the protective efficiency of LT was $~ 94 \%$; so it can be employed as an effective inhibitor in a wash-primer in order to replace chromates. The as formulated wash-primer performed satisfactorily in electrochemical and accelerated tests.

\section{MATERIALS AND METHODS}

2.1. Synthesis and Characterization of LT. Two commercial Tara tannins were selected for this research. One of them, T40, is a tannin obtained by extraction with ethanol, whereas the other, T80, was extracted with more polar solvents like acetone. From now on, Tara tannins will be referred to as "TT" and their derivatives precipitated with lanthanum salts as "LT". The number " 40 " and " 80 " will indicate the extraction performed with different solvents.

Solutions of TT40 and TT 80 were prepared from $10 \mathrm{~g}$ of the corresponding commercial Tara tannins by extraction with 300 $\mathrm{mL}$ of distilled water (DW) at $90{ }^{\circ} \mathrm{C}$ during $1 \mathrm{~h}$. Stirring was continued for $24 \mathrm{~h}$; then, the solids were filtered off and the solutions were brought to a final volume of $1000 \mathrm{~mL}$ with DW. Then, $50 \mathrm{~mL}$ of the as prepared solutions were mixed with increasing volumes of $\mathrm{La}\left(\mathrm{NO}_{3}\right)_{3} \times 6 \mathrm{H}_{2} \mathrm{O} 0.1 \mathrm{M}$ at $\mathrm{pH} 8$, under continuous stirring for $1 \mathrm{~h}$. The precipitate obtained in each case was washed with DW and allowed to dry during $24 \mathrm{~h}$ at $100{ }^{\circ} \mathrm{C}$. The LT precipitation curves were obtained in this way to select the respective synthetic pathways of LT40 and LT80 pigments. The as obtained precipitates were characterized by FTIR spectroscopy by means of a PerkinElmer Spectrum One Spectrometer. FTIR spectra were used to control that undesirable substances (like oxides) did not precipitate together with LT after the addition of the lanthanum salt.

In order to obtain the mass of $\mathrm{La}$ (III) that reacted with Tara tannin, the LT precipitate was heated at $850{ }^{\circ} \mathrm{C}$. The solid obtained after calcination was identified by XRD as $\mathrm{La}(\mathrm{OH})_{3}$ (JCPDF\# 36-1481). The content of tannin in the saturated solution was determined employing Folin-Denis reagent. ${ }^{27,40,41}$ The concentration of $\mathrm{La}$ (III) in this solution was determined by the oxalate method followed by further calcination of the precipitate at $900{ }^{\circ} \mathrm{C}$ which was weighed as the corresponding oxide. $^{42}$

The inhibitive properties of LT40 and LT80 were assessed by electrochemical techniques in the corresponding pigment suspensions in $\mathrm{NaCl} 0.1 \mathrm{M}$. The pigments suspensions were prepared by dispersing $1.0 \mathrm{~g}$ of each pigment in $100 \mathrm{~mL}$ of the supporting electrolyte with continuous stirring during 1 day to achieve complete saturation. The corrosion potential of a SAE 1010 steel electrode was measured as time elapsed, with respect to a reference, the saturated calomel electrode (SCE). The polarization resistance technique ${ }^{43,44}$ was employed to obtain corrosion rates with a three electrode cell. A SAE 1010 steel rod (area: $0.28 \mathrm{~cm}^{2}$ ) was the working electrode, the SCE the reference and a $\mathrm{Pt}$ mesh the counterelectrode. The sweep amplitude was $\pm 20 \mathrm{mV}$ o.c. and the scan rate $0.5 \mathrm{mVs}^{-1}$. All electrochemical measurements were done with a GAMRY Interface 1000 potentiostat in normally aerated solutions stirred at $300 \mathrm{rpm}$. A cell like that described previously was used to obtain polarization curves but in a wider potential range; \pm 250 $\mathrm{mV}$ oc.

In every case, the behavior of the steel electrode in Tara tannin suspensions were also carried out for concentrations of tannin comprised between 2 and 12 ppm.

2.2. Elaboration and Application of Wash-Primers Containing LT and an Alkyd Paint System. The washprimer was prepared on the basis of a tetroxychromate formulation reported elsewhere ${ }^{45}$ which consisted of two components called part $\mathrm{A}$ and part $\mathrm{B}$. The model primer contained zinc tetroxychromate as the inhibitive pigment and phosphoric acid. The dispersion of the film forming material, 
Table 1. Wash Primers Composition

\begin{tabular}{|c|c|c|c|c|c|c|c|}
\hline & formulation $\mathrm{v} / \mathrm{v} \%$ & TT 40 & LT 40 & TT 80 & LT 80 & Talc & ZTC \\
\hline \multirow[t]{7}{*}{ part A } & polyvinyl butyral resin & 8.20 & 8.20 & 8.20 & 8.20 & 8.20 & 8.20 \\
\hline & pigment & 2.20 & 2.20 & 2.20 & 2.20 & & 2.20 \\
\hline & talc & 0.47 & 0.47 & 0.47 & 0.47 & 2.67 & 0.47 \\
\hline & carbon black & 0.05 & 0.05 & 0.05 & 0.05 & 0.05 & 0.05 \\
\hline & butanol & 22.79 & 22.79 & 22.79 & 22.79 & 22.79 & 22.79 \\
\hline & isopropanol & 64.16 & 64.16 & 64.16 & 64.16 & 64.16 & 64.16 \\
\hline & water & 2.13 & 2.13 & 2.13 & 2.13 & 2.13 & 2.13 \\
\hline \multirow[t]{4}{*}{ part B } & citric acid & 17.1 & 17.1 & 17.1 & 17.1 & 17.1 & 17.1 \\
\hline & water & 14.0 & 14.0 & 14.0 & 14.0 & 14.0 & 14.0 \\
\hline & isopropanol & 68.9 & 68.9 & 68.9 & 68.9 & 68.9 & 68.9 \\
\hline & PVC & 0.25 & 0.25 & 0.25 & 0.25 & 0.25 & 0.25 \\
\hline
\end{tabular}

the polyvinyl butyral resin, ${ }^{46}$ and the anticorrosion pigments constituted part A of the primer while phosphoric acid and solvents are stored as part B. Zinc tetroxychromate was replaced, by volume, by the anticorrosion pigments LT40 and LT80 respectively to formulate the more eco-friendly washprimer. Phosphoric acid needed to be replaced by citric acid to avoid the precipitation of lanthanum phosphate. The composition of both parts of the primer, part A and part B, is sketched in Table 1 . As the properties of the coatings depend on the pigment volume concentration and its relationship with the critical pigment volume concentration (CPVC), ${ }^{47-49}$ the composition of the primer was given by volume. The components of the Part A were dispersed in a ball mill during $24 \mathrm{~h}$ to achieve an acceptable dispersion degree (5 in Hegman gage). Solvents and citric acid were mixed to obtain Part B. Other primers formulations were obtained employing Tara tannin (TT40 and TT80) or talc which was used as control together with the chromate wash-primer. Sandblasted SAE 1010 steel panels were degreased with toluene before painting and part $A$ and $B$ were mixed as 4:1 by weight, respectively. The primers were applied by brushing. The final dry film thickness was $7 \pm 2 \mu \mathrm{m}$.

The anticorrosion behavior of the formulated wash-primers was studied by electrochemical techniques: corrosion potential and ionic resistance variations were measured as a function of time. The ionic resistance was obtained with a Pt counterelectrode employing an ATI ORION model 170 conductimeter, at $1000 \mathrm{~Hz}$. The corrosion rate of primed steel was also determined following the procedure described in the preceding paragraph. Taking into account that the primers possessed low ionic resistance, it was possible to determine the corrosion rates by the linear polarization method. ${ }^{50}$

Primed steel panels were submerged $24 \mathrm{~h}$ in DW. Afterward, the coating was removed with a suitable solvent, like acetone, to observe the morphology of the protective layer formed on steel panels by means of a scanning electron microscope (SEM), FEI Quanta 200 with tungsten filament. The surface elemental composition of the protective film formed on steel panels was determined with an energy dispersive RX microanalyzer and the EDX detector Apollo 40.

2.3. The Performance of the Wash-Primer in an Alkyd Paint System. 2.3.1. Formulation, Elaboration, and Application of the Alkyd Paints. The anticorrosion behavior of the wash-primers was assessed by incorporating them in a complete painting scheme constituted by the primers, an anticorrosion alkyd paint and a top coat alkyd coating. The dry film thickness of each alkyd coat was $35 \mu \mathrm{m}$.
The binder employed to formulate the coatings was a solvent-borne-medium oil alkyd (50\% linseed oil, 30\% o-phtalic anhydride, $8 \%$ pentaerythritol and glicerol and $12 \%$ pentaerythritol resinate). The solvent was white spirit. It was decided to check the anticorrosive properties of the pigments employing solvent borne paints because their behavior has been well documented for many years. The PVC/CPVC relationship was 0.8 as suggested in previous researchs. ${ }^{51,52}$

The composition of the anticorrosive paint, expressed as percentage by volume, was: zinc molybdenum phosphate, 6.54\%; non fibrous magnesium silicate, $6.37 \%$; barite, $6.20 \%$; titanium dioxide, $2.55 \%$; alkyd resin: white spirit (1:1), $60.23 \%$ and solvents, $18.11 \%$. The topcoat composition v/v \% was: titanium dioxide, 10.8\%; alkyd resin: white spirit (1:1), 66.2\%; and solvent, 23\%. All pigments were dispersed $24 \mathrm{~h}$ in the vehicle, employing a ball mill to achieve an acceptable dispersion degree.

2.3.2. The Performance of Anticorrosive Paints through Accelerated Tests. A set of three panels was placed in the salt spray chamber (ASTM B 117) to evaluate the rusting and the blistering degrees (ASTM D 610 and ASTM D 714, respectivelly). Painted panels were evaluated during 90 days. The mean value of the obtained results was reported in this paper. Similar panels were placed in the humidity chamber (ASTM D 2247); and blistering and rusting degrees were evaluated during 30 days.

Impedance spectra of painted panels were performed in the potentiostatic mode, at the corrosion potential $\left(E_{\text {corr }}\right)$. Two acrylic tubes were attached to each coated panel (working electrode) with an epoxy adhesive; the area exposed to the electrolyte, in each cell, was $15.9 \mathrm{~cm}^{2}$. Measurements were carried out as a function of the exposure time in $3 \% \mathrm{NaCl}$, using the 1255 Solartron FRA and the 1286 Solartron EI. A large area $\mathrm{Pt}-\mathrm{Rh}$ mesh of negligible impedance and saturated calomel (SCE) were employed as auxiliary and reference electrodes, respectively. The amplitude of the applied AC voltage was $0.010 \mathrm{~V}$ peak to peak. The frequency range employed was $1 \times 10^{5} \mathrm{~Hz} \leq f \leq 1 \mathrm{~Hz}$ ). The experiments were carried out at laboratory temperature $\left(20 \pm 2{ }^{\circ} \mathrm{C}\right)$, using a Faraday cage. The experimental impedance spectra were interpreted on the basis of equivalent electrical circuits using the procedure developed by Boukamp. ${ }^{53}$ Simultaneously, corrosion potential values were recorded as a function of immersion time. 


\section{RESULTS AND DISCUSSION}

\subsection{Pigment Preparation and Characterization.} Previous research shows the convenience of precipitating LT at $\mathrm{pH} 8 .{ }^{54}$ The two precipitation curves (LT40 and LT80) were similar. The mass of precipitated lanthanum tannate increased as the added volume of $0.1 \mathrm{M} \mathrm{La}\left(\mathrm{NO}_{3}\right)_{3}$ increased but both curves reached a "plateau" when $30.0 \mathrm{~mL}$ of $\mathrm{La}(\mathrm{III})$ solution were added. This volume is the adequate one to precipitate the corresponding lanthanum tannates from $50 \mathrm{~mL}$ of tannin solution. Beyond this volume, the amount of precipitated tannate did not increase significantly. The mass of precipitate was a little higher for TT80 (Figure 1). According to previous

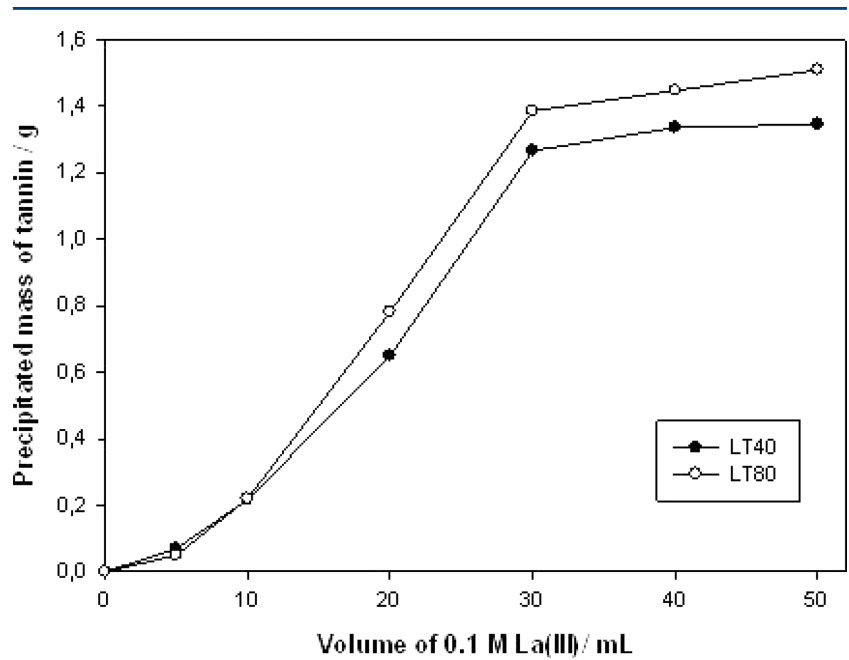

Figure 1. Mass of tannin precipitated as a function of the volume of $0.1 \mathrm{M} \mathrm{La}\left(\mathrm{NO}_{3}\right)_{3}$ at $\mathrm{pH} 8$.

results, the precipitation of the corresponding tannates was accomplished by mixing $50 \mathrm{~mL}$ of the tannin solution with 30.0 $\mathrm{mL}$ of $0.1 \mathrm{M} \mathrm{La}\left(\mathrm{NO}_{3}\right)_{3} \times 6 \mathrm{H}_{2} \mathrm{O} 0.1 \mathrm{M}$ at $\mathrm{pH} 8$, under continuous stirring during $1 \mathrm{~h}$. The precipitate obtained in each case was washed with DW and dried for $24 \mathrm{~h}$ at $100{ }^{\circ} \mathrm{C}$.

The main components of Tara tannins are gallotannins $(\sim 53.1 \%)$. They may also contain ellagitannins $(\sim 6.9 \%)$ and gallic acid $(\sim 9.5 \%) ;^{28}$ in this sense it was expected that FTIR spectra of TT40 and TT80 Tara tannins were similar to each other (Figure 2). Both spectra presented the same set of absorption bands. Band assignment was accomplished by a suitable chart published elsewhere. ${ }^{55-57}$

A wide band associated with the $\mathrm{OH}$ stretching from different chemical environments was observed for the region 3600 to $3000 \mathrm{~cm}^{-1}$ which is characteristic of the polyphenolic extracts. As a consequence of the great number of phenolic groups the absorption band is wide and the three bands in the range $3100-3000 \mathrm{~cm}^{-1}$, characteristics of the aromatic ring, could not be appreciated in the corresponding spectra. The band in this region was broader in the case of the aqueous extract due to the hydration of both tannins.

The band located at $1690 \mathrm{~cm}^{-1}$ could be attributed to ester unions which are the result of the esterification of gallic acid units and a hydroxyl group from a polyol as it occurs in gallotannins and ellagitannins.

Bands related to the vibrations of the $\mathrm{C}=\mathrm{C}$ aromatic bond at 1610,1537 , and $1455 \mathrm{~cm}^{-1}$ were also detected for both tannins. Actually, four bands could be detected in the $1450-1600 \mathrm{~cm}^{-1}$
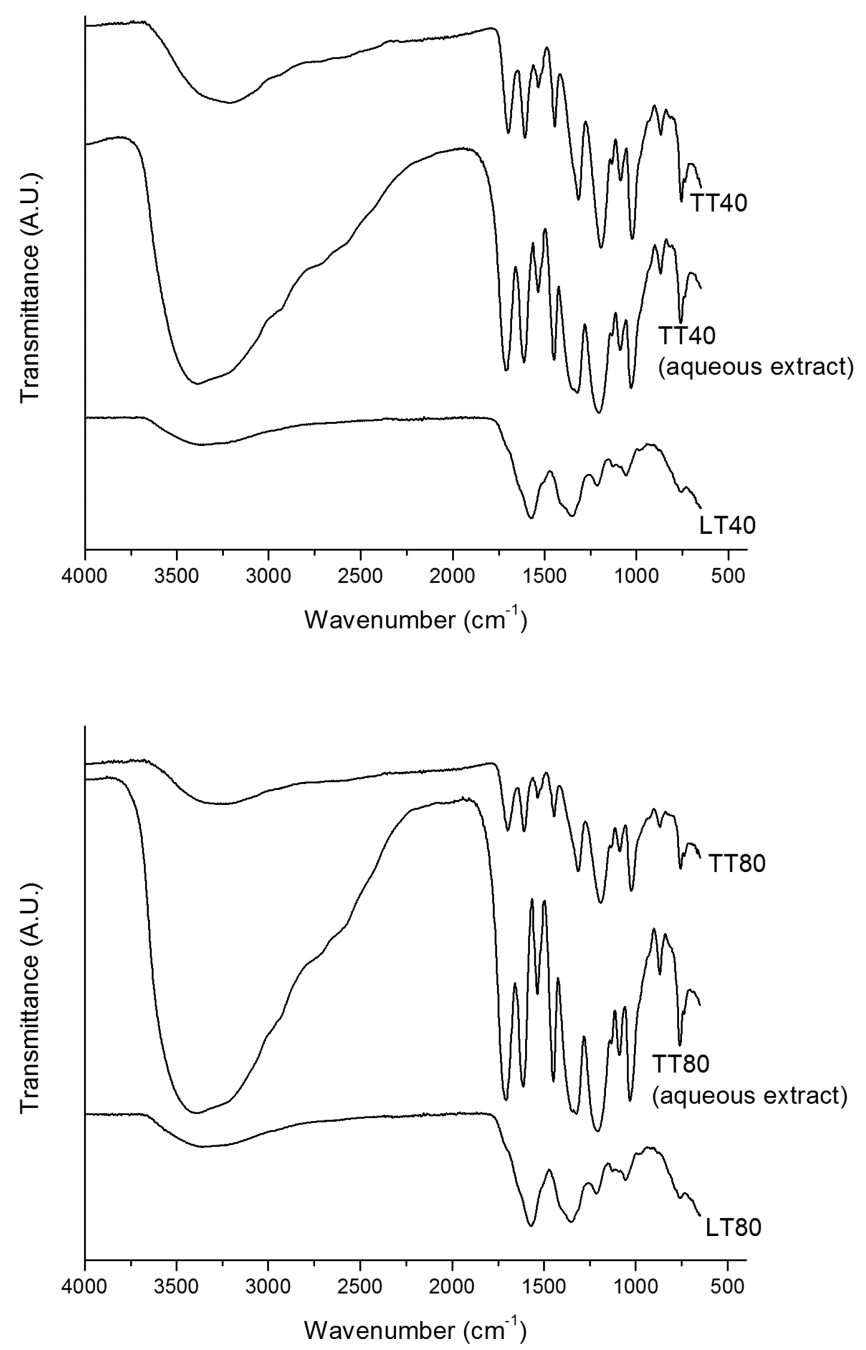

Figure 2. FTIR spectra of tannins (TT40 and TT80), their aqueous extracts and their derivatives (LT40 and LT80).

but, sometimes, the band at $1580 \mathrm{~cm}^{-1}$ overlapped with the band at $1610 \mathrm{~cm}^{-1}$.

The stretching of $\mathrm{C}-\mathrm{O}$ groups present in ester linkages were detected at 1318, 1203, and $1024 \mathrm{~cm}^{-1}$. The deformation of the aromatic $\mathrm{C}-\mathrm{H}$ bond in the plane was located at 1138 and 1097 $\mathrm{cm}^{-1}$, respectively, whereas the band corresponding to the $\mathrm{C}-$ $\mathrm{H}$ deformation out of the plane was found at $\sim 830 \mathrm{~cm}^{-1}$.

Spectra of the dried extracts were similar to those of the tested tannins, TT40 and TT80, respectively.

As it occurred with tannins, the FTIR spectra corresponding to the tannates are similar to each other and they maintain a certain relationship with those of TT40 and TT80 Tara tannins. However, some changes were observed. As the ester bonds hydrolyzed at $\mathrm{pH} 8$ at which lanthanum tannates were prepared, the band at $1690 \mathrm{~cm}^{-1}$ disapeared. In change, two broad absorption bands centered at 1573 and $1339 \mathrm{~cm}^{-1}$ appeared. The first band was attributed to the carboxylate anion formed after hydrolysis. This group reacted with $\mathrm{La}$ (III) to form the corresponding tannate. The other absorption band was assigned to the $\mathrm{C}-\mathrm{OH}$ vibration. Some of the absorption bands present in the tannin spectra, close to these new bands, appeared as shoulders of them (Figure 2). The $\mathrm{La}_{2} \mathrm{O}_{3}$ absorption bands, which are normally found at 464 and 571 
$\mathrm{cm}^{-1}$, are not observed. This fact confirmed that lanthanum tannate is precipitating instead of lanthanum oxide.

The solubility of tannin as determinated by the Folin-Denis reagent was lower than $1 \mathrm{ppm}$ for both tannates. The concentration of $\mathrm{La}$ (III) in the saturated solutions was very low $\left(<2.2 \times 10^{-6} \mathrm{M}\right)$ because it was completely precipitated to form LT40 and LT80. As no precipitate was formed by the oxalate method to determine $\mathrm{La}$, it was concluded that the $\mathrm{La}$ (III) content was under the detection limit. The content of $\mathrm{La}(\mathrm{III})$ in LT40 and LT80 was determinated by calcination and it was found to be $26.0 \%$ for LT40 and $28.0 \%$ for LT 80 . This fact indicated that both LT40 and LT80 can act as a reservoir of La(III).

As a trend, for both tannins, at a given immersion time, Icorr increased as the concentration of tannin increased. None of the solutions seemed to inhibit satisfactorily steel corrosion, the lowest corrosion rates were obtained with the most diluted solution $(2 \mathrm{ppm})$. In many cases, tannin solutions were more aggressive than the supporting electrolyte. This behavior could be explained taking into account the $\mathrm{pH} 3$ of the TT suspensions and is in complete agreement with results of Ecorr measurements. In change, steel Icorr was highly reduced in the tannate suspensions. LT obtained from Tara tannin TT40 was more effective than the other tannate. The inhibitive efficiency, in the case of lanthanum tannate obtained with Tara tannin TT40, was $95 \%$ after $24 \mathrm{~h}$ while this efficiency matched $86 \%$ for the LT precipitated from Tara tannin TT80 (Supporting Information (SI) Table S1).

Steel Ecorr in TT solutions was displaced, with respect to the blank (steel in the supporting electrolyte), to more negative values. The displacement may be higher than $200 \mathrm{mV}$, particularly at the beginning of the test period. This fact may be attributed to the low $\mathrm{pH}$ of the TT solutions $(\mathrm{pH} 3)$. In every case steel was active, dissolving itself to generate a film of iron tannate. In this sense, it is interesting to point out that, during the first minutes of immersion, Ecorr of steel was very negative and increased as time elapsed. However, there are no significant differences among the three concentrations of TT40 employed in this assay and, at the end of the test, Ecorr fluctuated around $-0.600 \mathrm{~V}$. In change, steel Ecorr values in the lanthanum tannate suspension revealed that the substrate became passivated. At the beginning of the exposure time and during $50 \mathrm{~min}$ Ecorr increased from around $-0.300 \mathrm{~V}$ to finally fluctuate around $-0.216 \mathrm{~V}$ (Figure 3). TT80 presented a similar behavior but steel Ecorr in LT80 suspensions resulted $\sim 0.100 \mathrm{~V}$ more negative than in the case of LT40 (Figure 4).

Polarization curves showed that, in the presence of tannates, steel is active. In change, lanthanum tannates restrained steel dissolution. The cathodic current is also lower in the presence of these tannates (SI Figure S1).

3.2. Wash-Primer Characterization. The primer containing zinc tetroxychromate (ZTC) displaced steel Ecorr to more positive values with respect to the other primers. All the primers formulated with a TT or its derivative showed a similar behavior. At the beginning of the test period, very negative potentials were measured and they may be related to metal dissolution and the formation of a protective film mainly composed by iron tannates. This displacement was more important in the case of the primer containing LT. As time went on, Ecorr decreased for the ZTC primer, and it increased for the other primers, so at the end of the testing period the values did not differ significantly. In every case, Ecorr

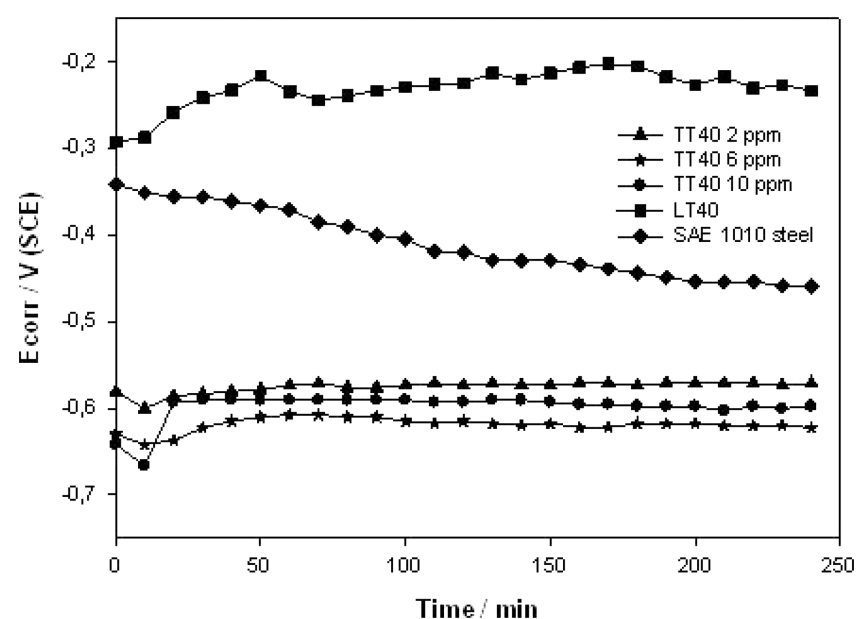

Figure 3. Steel corrosion potential in TT40 and LT40 suspensions in $0.025 \mathrm{M} \mathrm{NaCl}$.

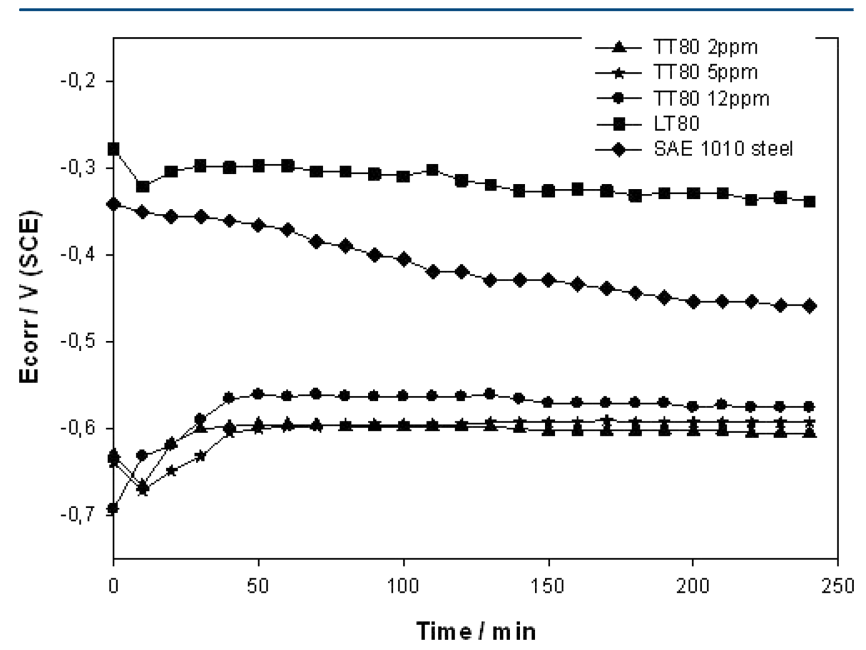

Figure 4. Steel corrosion potential in TT80 and LT80 suspensions in $0.025 \mathrm{M} \mathrm{NaCl}$.

corresponded to the formation of iron oxides which grew together with iron tannates (Figures 5 and 6).

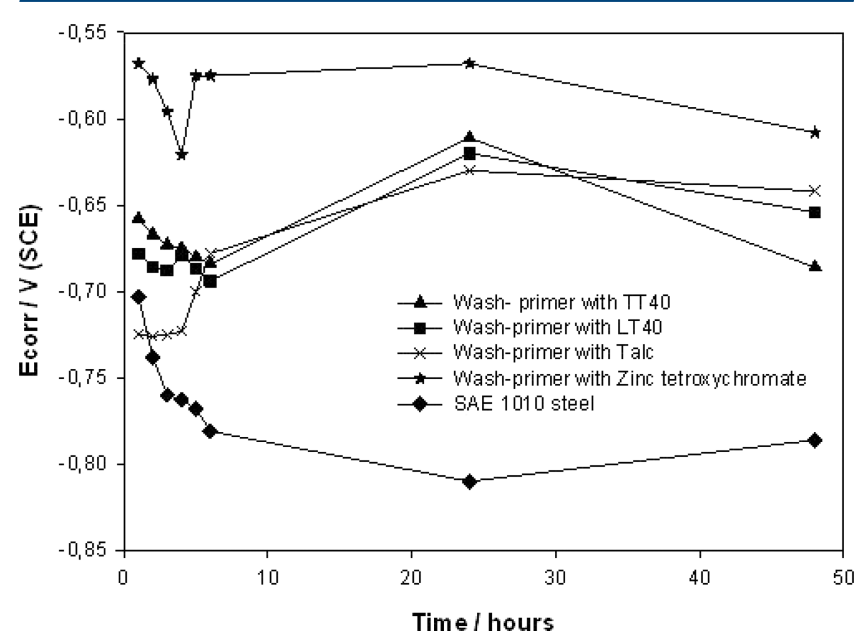

Figure 5. Steel corrosion potential of primed panels with TT40 or its derivative LT40, as a function of time in $0.025 \mathrm{M} \mathrm{NaCl}$. 


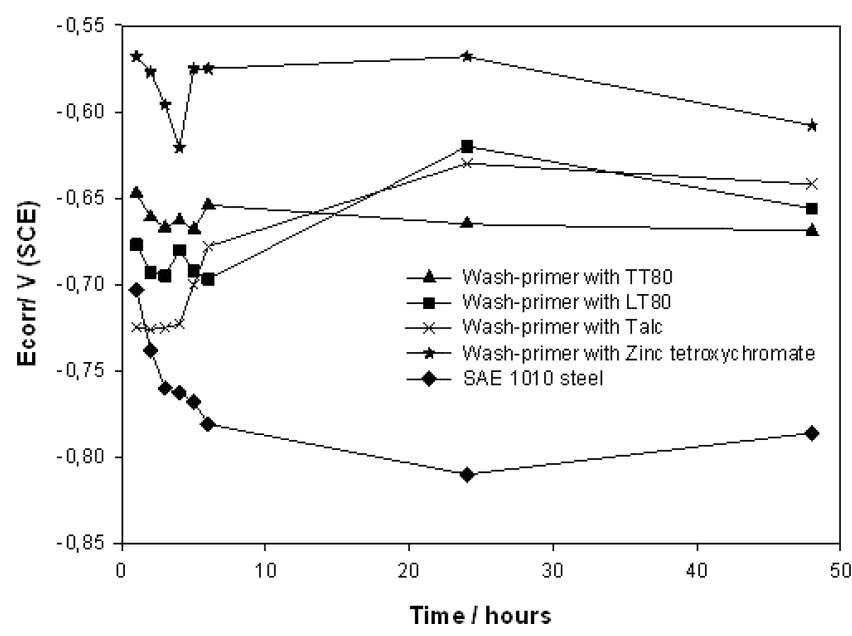

Figure 6. Steel corrosion potential of primed panels with TT80 or its derivative LT80, as a function of time, in $0.025 \mathrm{M} \mathrm{NaCl}$.

None of the tested system possessed barrier properties; so, the control of the corrosion process was mostly, in nature, kinetic. ${ }^{58-60}$ The ionic resistance of the primers formulated with talc and zinc tetroxychromate was rather low. The ionic resistance of the films originated by the primers containing TT40 and LT40 as pigments increased continuously as time elapsed during the first hours, then dropped off to a final value that did not differ significantly from the other primers (Figure 7). The increased resistance could be explained by pore

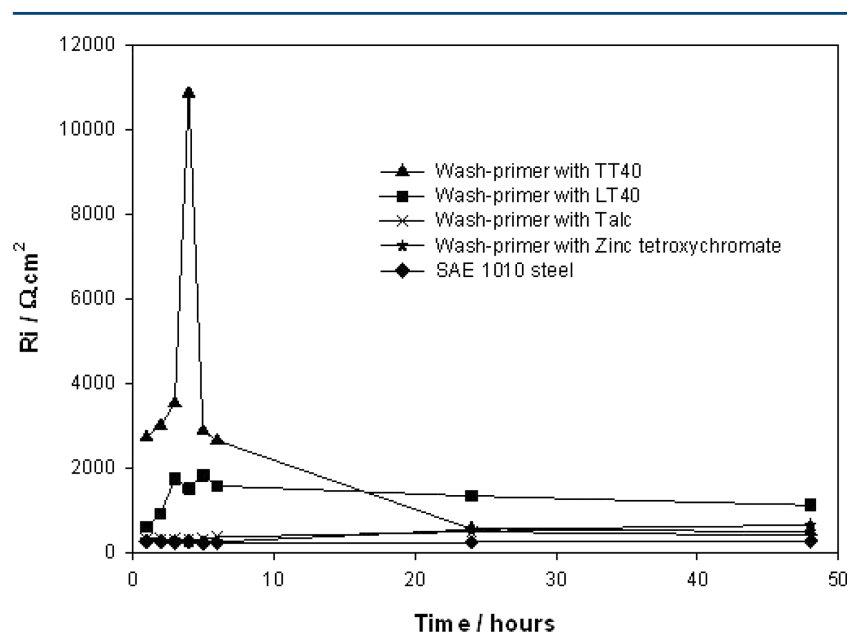

Figure 7. Ionic resistance of primed panels with TT40 or its derivative LT40, as a function of time, in $0.1 \mathrm{M} \mathrm{NaCl}$.

plugging due to corrosion products. It may be observed that the ionic resistance of the primers formulated with TT40 and LT40 is ten times higher than that of the primers containing TT80 and LT80. This fact would foresee better barrier properties in the first case (Figures 7 and 8).

The primer containing ZTC was the most effective in reducing the corrosion rate of steel (icorr). icorr did not change significantly along the test. Initially, steel corrosion rate of the panels coated with the rest of the primers was greater than that of the ZTC primer. After $3 \mathrm{~h}$ of immersion steel corrosion rate of all primed panels was similar to each other. The corrosion rate of these primers begun to increase after $5 \mathrm{~h}$; it continued increasing until the end of the test period. Steel corrosion rate for the primers pigmented with TT40 and LT40 were similar

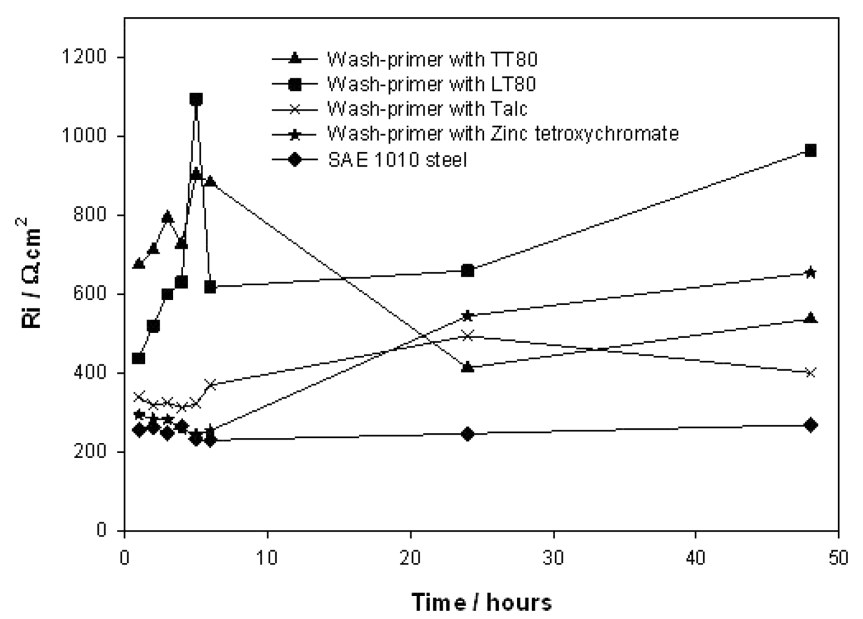

Figure 8. Ionic resistance of primed panels with TT 80 or its derivative LT80, as a function of time, in $0.1 \mathrm{M} \mathrm{NaCl}$.

while LT80 had better anticorrosive performance than TT80 (Figures 9 and 10).

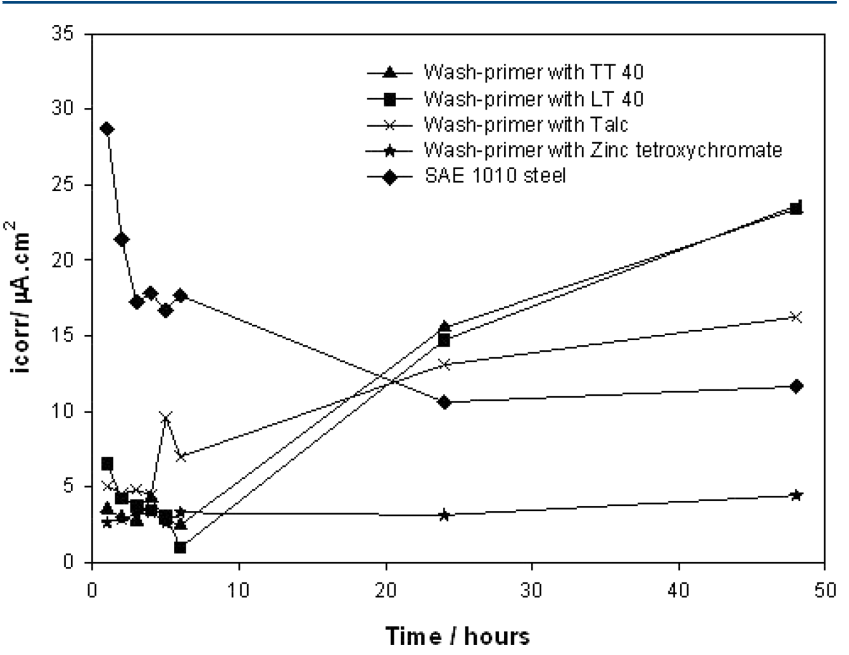

Figure 9. Corrosion rate of primed panels formulated with TT40 and LT40, as a function of time, in $0.1 \mathrm{M} \mathrm{NaCl}$.

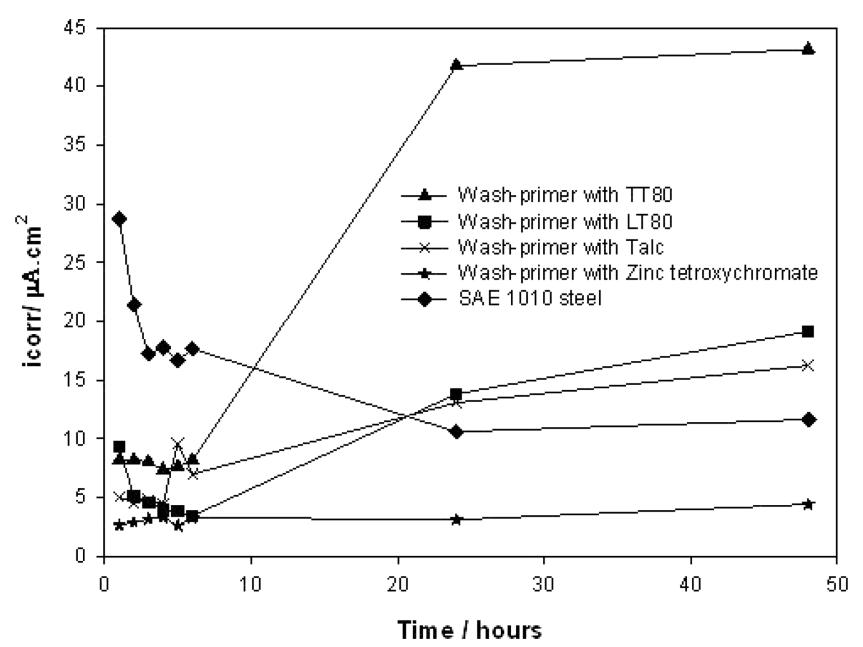

Figure 10. Corrosion rate of primed panels formulated with TT80 and LT80, as a function of time, in $0.1 \mathrm{M} \mathrm{NaCl}$. 
After SEM examination, the steel surface in DW seemed to be covered with an oxide layer partially destroyed by pitting (Figure 11a). The surface morphology was modified in both

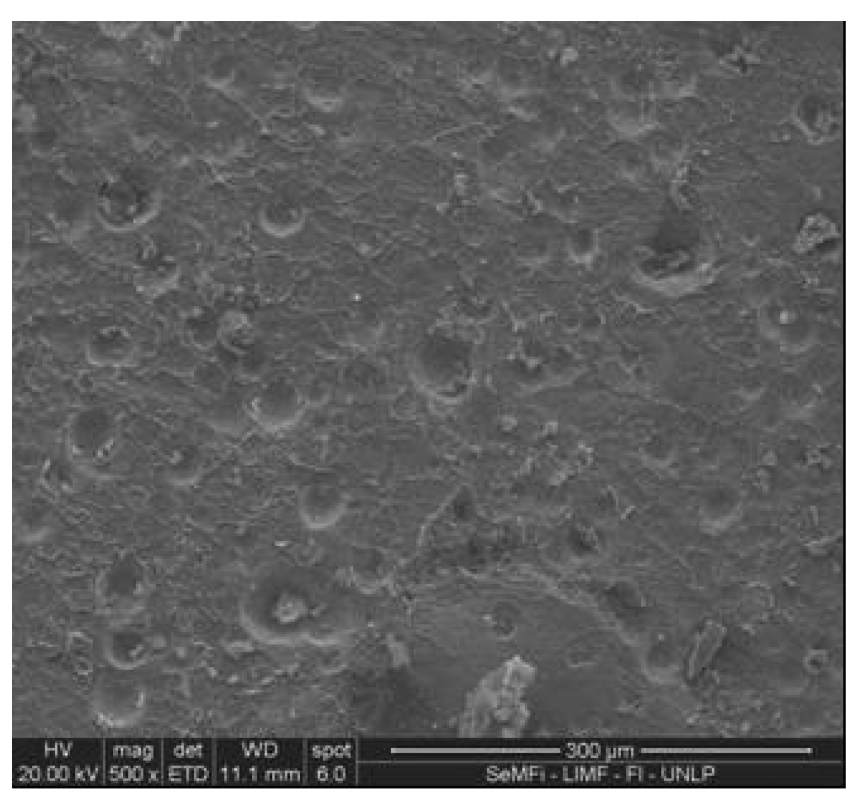

a

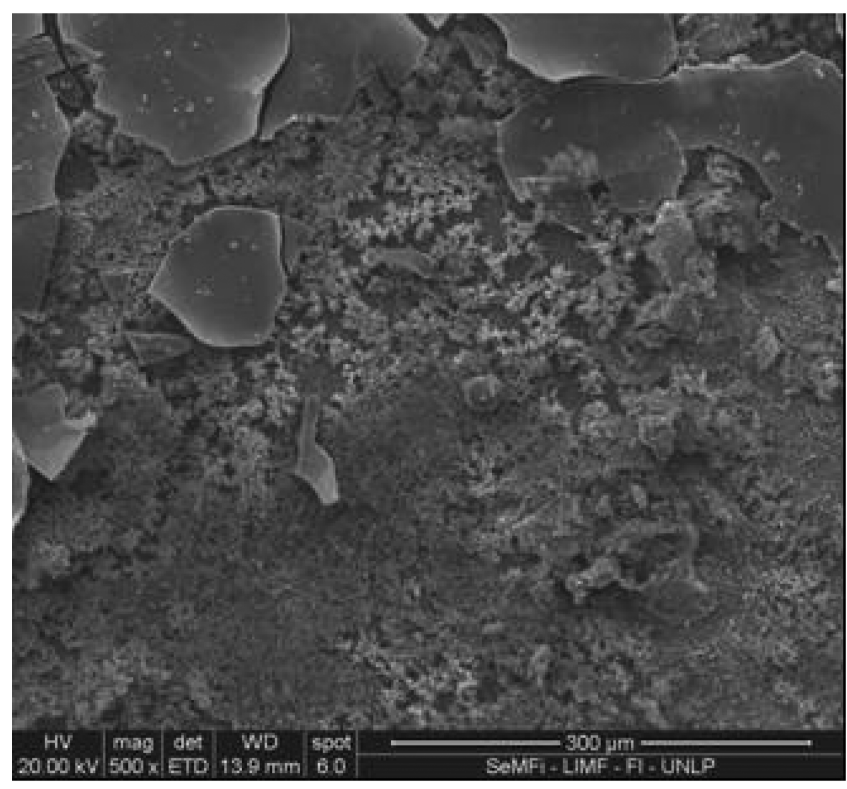

b

Figure 11. Steel surface morphology after $24 \mathrm{~h}$ of exposure: (a) in the supporting electrolyte, (b) TT40 suspension, (c) in TT80 suspension, (d) in LT40 suspension, (e) in LT80 suspension.

TT40 and TT80 suspensions. In the case of TT40 the protective film contained plates and powdery formations typical of tannins (Figure 11b). ${ }^{61}$ Pits were not detected (Figure 11b). The surface in contact with TT80 was quite different and many globular oxide formations could be observed. Pits were not observed, they may be covered with iron oxides (Figure 11c). The surface morphology in LT suspensions changed significantly. A very thin film covered the steel surface (Figure $11 \mathrm{~d}$ and e). It was considered that the protective film is thin because the polishing lines could be seen in both cases. According the surface elemental analysis both film contained C, probably due to the formation of a tannate coating. The content of La was very high in the case of the steel panel in contact with the LT40 suspension and nondetectable for the panel in the other suspension (Table 2).

Table 2. Lanthanum Tannate Film Composition after EDS Spectrum

\begin{tabular}{ccclc} 
\%Wt & C & O & \multicolumn{1}{c}{ La } & Fe \\
LT40 & 13.4 & 14.4 & 31.9 & 40.3 \\
LT80 & 5.71 & 0.49 & nondetectable & 93.8 \\
\hline
\end{tabular}

\subsection{The Behavior of the Wash-Primer in a Paint} System. After one and a half month of exposure, results in the accelerated tests (salt spray and humidity chambers) showed that all wash-primers had similar anticorrosion behavior than the primer formulated with ZTC.

In the salt spray chamber, the primer formulated with talc begun to fail after 52 days of exposure (SI Table S2). At longer exposure time (90 days), the primer containing LT40 (qualification $8 \mathrm{P}$ ) performed similar to the one formulated with ZTC (qualification 9P). The primers formulated with both tannins exhibited a slightly worse behavior than those pigmented with LT40.

Alkyd systems are prone to fail by blistering in the humidity chamber. All tested paints blistered after the first day of exposure (SI Table S3). Blistering did not change significantly in the case of the primers containing either tannins or tannates. Blistering was intense in the case of the primer containing ZTC and talc; the panels coated with these formulations were removed from the chamber after 31 days of exposure.

As a trend, the corrosion potential of painted panels was displaced to more positive values with respect to the steel corrosion potential (Ecorr $=-0.650 \mathrm{~V}$, Figure 12); particularly, at the beginning of the exposure time. The oscillating behavior was attributed to active-passive transitions.

As an example, Bode's plots corresponding to the painting schemes containing the primer formulated with TT40 and that pigmented with LT40 are shown in Figure 13a and b, respectively. The simple observation of these plots revealed that one or two time constants may appear depending on the exposure time.

Impedance data were fitted using equivalent circuits as those depicted in Figure 14, previously discussed in the literature. ${ }^{62,63}$ The first one, with only one time constant, describes the film properties. The second one was employed to fit experimental data once the corrosion process was started. The exact number of time constants was determined from the fitting of experimental data, according to the point of view adopted by Amirudin and Thierry. ${ }^{62}$

Distortions observed in the resistive-capacitive contributions indicate a deviation from the theoretical models due to either lateral penetration of the electrolyte at the steel/paint interface (usually started at the base of intrinsic or artificial coating defects), underlying steel surface heterogeneity (topological, chemical composition, surface energy) and/or diffusional processes that could take place along the test. Since all these factors cause the impedance/frequency relationship to be nonlinear, they are taken into consideration by replacing the capacitive components $\left(C_{\mathrm{i}}\right)$ of the equivalent circuit transfer function by the corresponding constant phase element $Q_{i}$ 


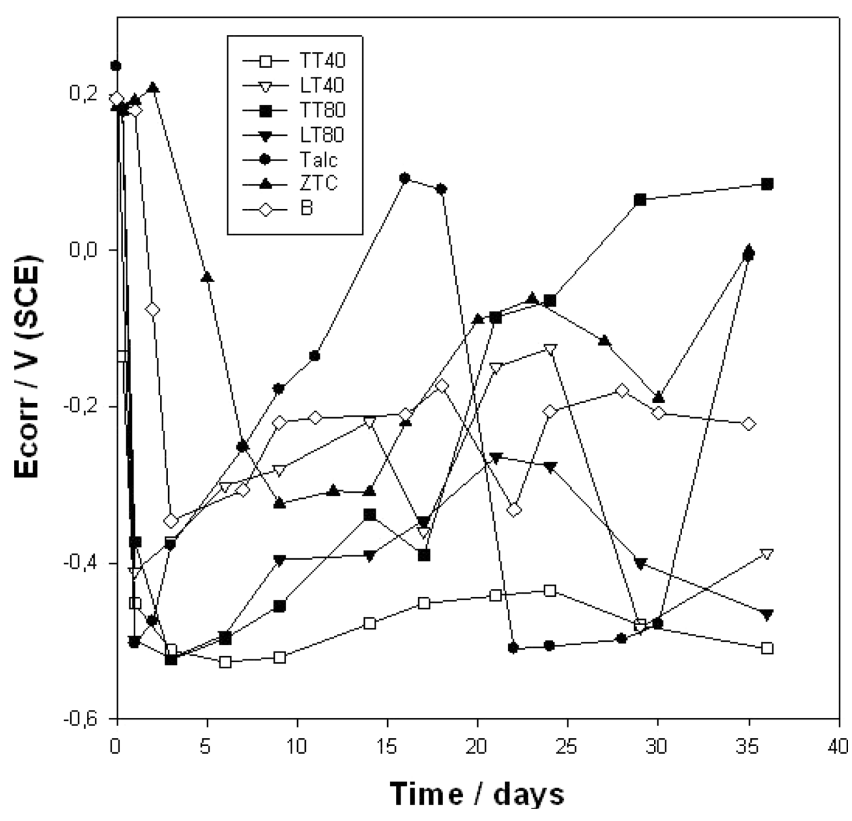

Figure 12. Corrosion potential of steel panels coated with the different painting schemes.

(CPE), thus obtaining a better fit of data. The CPE is defined by the following equation: ${ }^{64}$

$$
Z=\frac{(\mathrm{j} \omega)^{-n}}{\mathrm{Y}_{0}}
$$

where $Z \Rightarrow$ impedance of the CPE $\left(Z=Z^{\prime}+Z^{\prime \prime}\right)$. ( $(\Omega), j \Rightarrow$ imaginary number $\left(j^{2}=-1\right), \omega \Rightarrow$ angular frequency. (rad), $n$ $\Rightarrow$ CPE power $(n=\alpha /(\pi / 2)$. (dimentionless), $\alpha \Rightarrow$ constant phase angle of the CPE. (rad), $Y_{0} \Rightarrow$ part of the CPE independent of the frequency. $\left(\Omega^{-1}\right)$.

The accuracy of the fitting procedure was measured by the $\chi^{2}$ parameter obtained from the difference between experimental and fitted data; the most probable circuit was selected providing that $\chi^{2}<10^{-4}$.

In the present work, the fitting process was mainly performed using the phase constant element $\mathrm{Q}_{i}$ instead of the dielectric capacitance $C_{\mathrm{i}}$. However, this last parameter was used in the plots in order to facilitate results visualization and interpretation. As an example, the result of the fitting process, corresponding to one paint scheme and one and two time constants is presented in SI Figure S2.

The barrier properties of the painting scheme depended on the alkyd paints because the ionic resistance of the primers was low (Figure 15). All the paint systems tested showed a full barrier to ion diffusion at the beginning of the immersion period as it could be deduced from the pore resistance (R1) values which were higher than $1.0 \times 10^{8} \Omega \cdot \mathrm{cm}^{2}$; the threshold value suggested in the literature. ${ }^{65,66}$ The exception was the painting scheme without primer (Figure 15a, blank). Afterward, all the paint systems maintained a residual protection $\left(10^{6} \Omega\right.$. $\mathrm{cm}^{2}<\mathrm{R} 1<10^{8} \Omega \cdot \mathrm{cm}^{2}$ ) except that formulated with LT80 (Figure 15b). The differences observed among the different paint systems could be attributed to different interactions between each coating. R1 oscillations, as time elapsed, could be explained by the pore plugging-unplugging due to corrosion products.

The highest value of the charge transfer resistance (R2) was obtained for the paint system containing the wash-primer
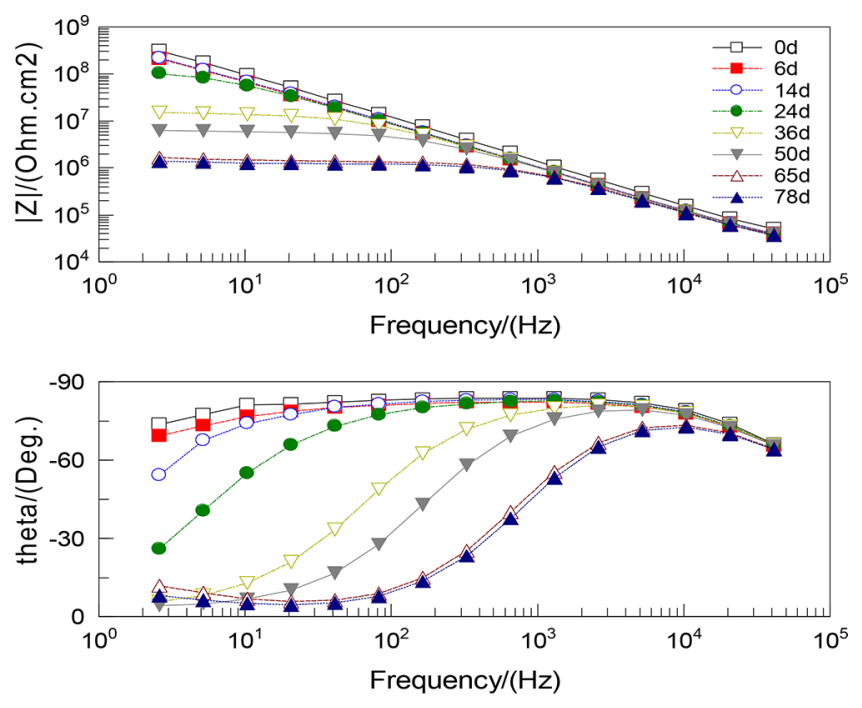

a
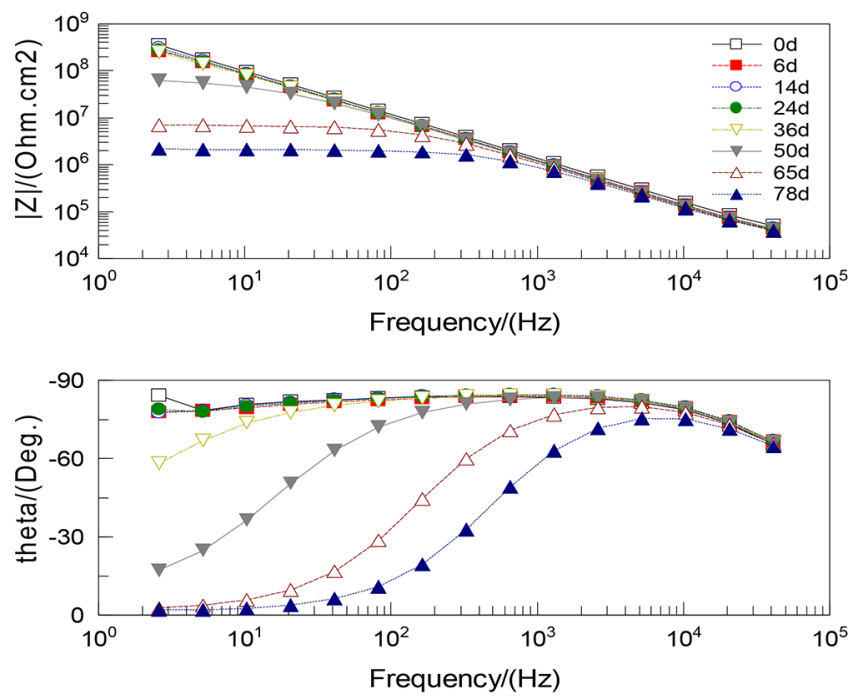

b

Figure 13. Bode's plots: (a) painting scheme containing the washprimer pigmented with TT40; (b) painting scheme containing the wash-primer pigmented with LT40.

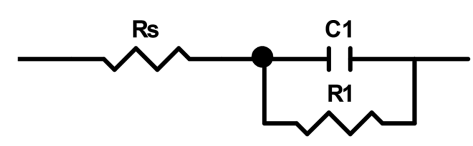

a

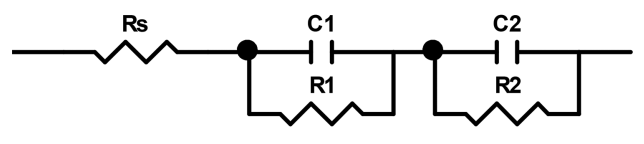

b

Figure 14. Equivalent circuits employed to fit experimental data.

pigmented with ZTC. However, most of all the measured values were comprised between $10^{7}-10^{8} \Omega \cdot \mathrm{cm}^{2}$, at least during the first 3 weeks of immersion; thus revealing that these systems could also protect steel from corrosion. As a trend, the 


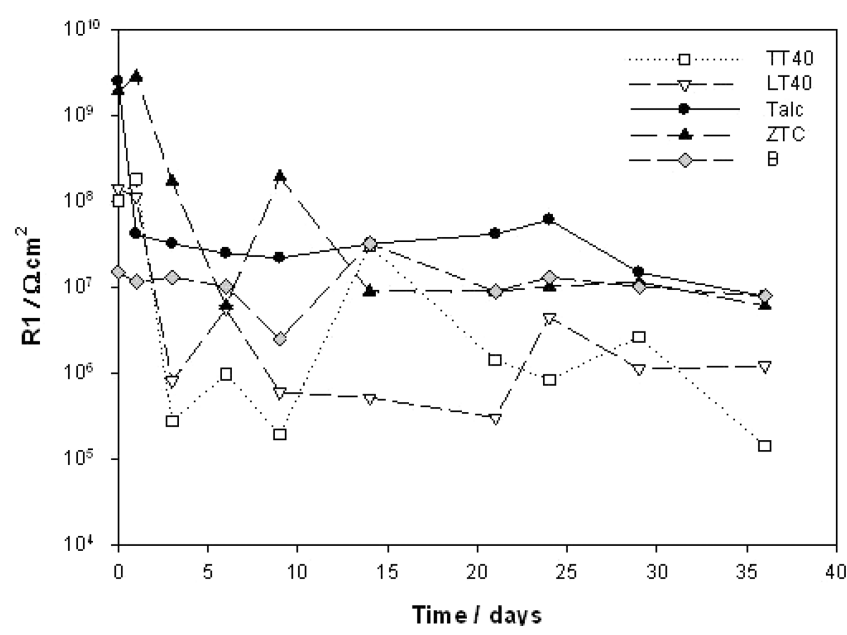

a

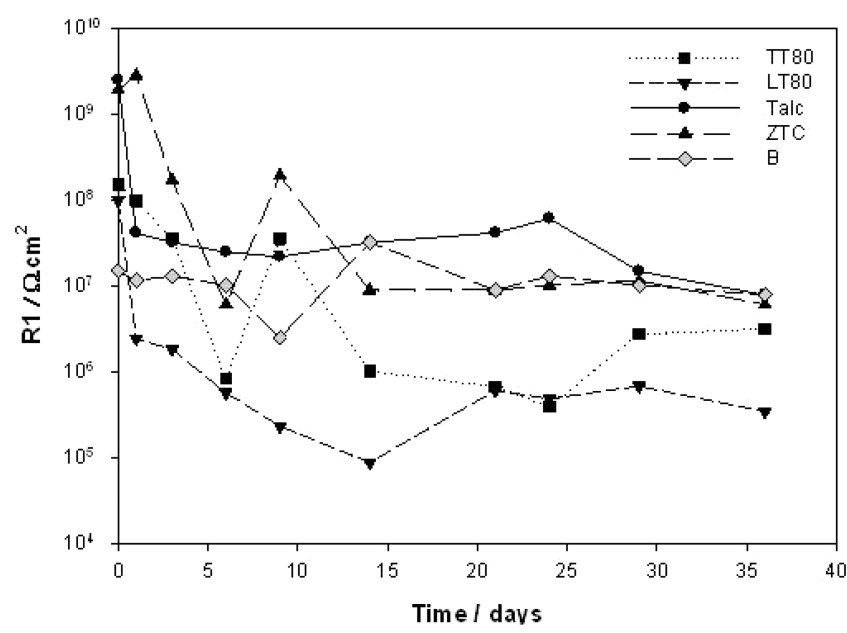

b

Figure 15. Pore resistance of steel panels coated with the different painting schemes: (a) TT40 and its derivative LT40; (b) TT80 and its derivative LT80.

charge transfer resistance of the systems with a wash-primer was higher than that of the control, thus increasing the resistance of the coated metal to corrosion (Figure 16a and b). It must be pointed out that the corrosion process was delayed in some cases which was evidenced by the absence of the $\mathrm{R} 2 \mathrm{C} 2$ time constant in certain periods of time, particularly at the beginning of the immersion time. The corrosion process was delayed 3 weeks in the case of the primer containing LT40 while it was detected from the very beginning of the test period in the case of the wash-primer formulated with ZTC.

The values of the film capacitance $(\mathrm{C} 1)$ pointed out that all tested systems showed an incipient loss of integrity $\left(\mathrm{C} 1>10^{-9}\right.$ $\mathrm{Fcm}^{-2}$, Figure 17a and b). The best behavior was observed for the paint system with the primers containing either ZTC or talc.

The capacitance of the double layer (C2) was almost 2 orders of magnitude lower for the systems containing the different wash-primer (Figure 18a and b). There are no significant differences between the tested paint systems containing a wash-primer. The presence of these primers in the paint system reduced the electrochemical active area.

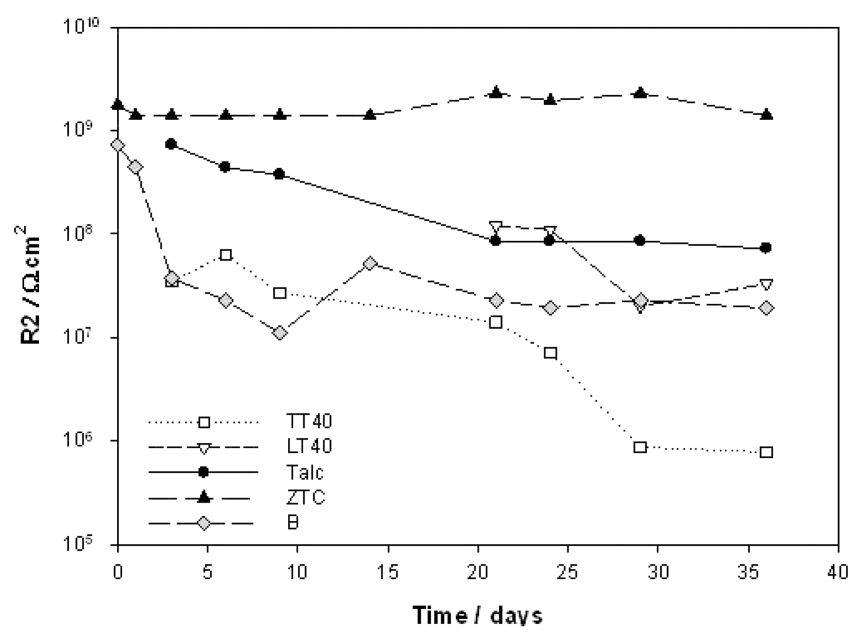

a

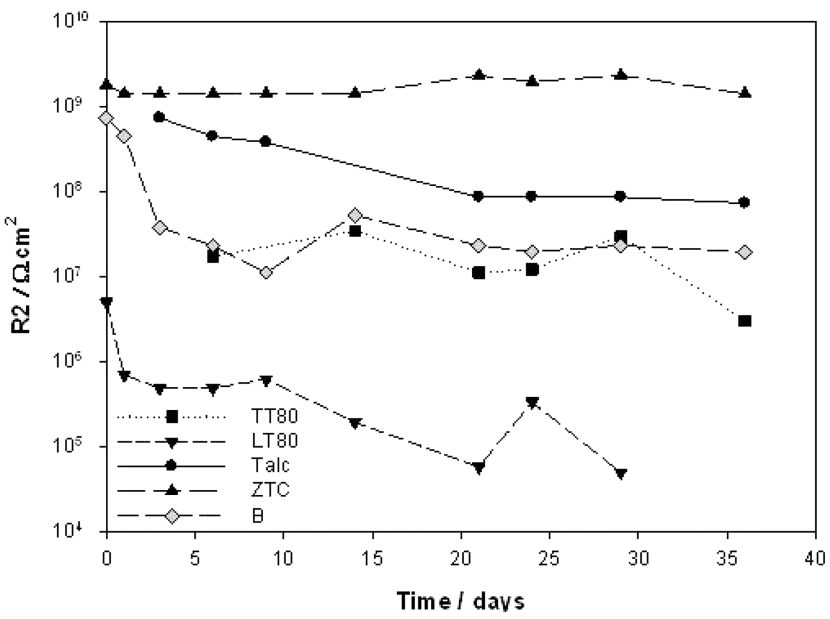

b

Figure 16. Charge transfer resistance of steel panels coated with the different painting schemes: (a) TT40 and its derivative LT40; (b) TT80 and its derivative LT80.

\section{CONCLUSIONS}

1. The optimum relationship mmoles $\mathrm{La}\left(\mathrm{NO}_{3}\right)_{3} /$ mass of Tara tannin to precipitate the lanthanum tannate was 3 $\mathrm{mmol} / 0.50 \mathrm{~g}$ at $\mathrm{pH}$ 8. Tara tannins were completely precipitated at $\mathrm{pH} 8$ as it could be deduced from the solubility of both lanthanum tannates.

2. Both lanthanum tannate (LT40 and LT80) can act as a reservoir of $\mathrm{La}(\mathrm{III})$ due to their content of $\mathrm{La}(\mathrm{III})$ (26.0\% for LT40 and $28.0 \%$ for LT80, respectively).

3. Tara tannin solutions could be more aggressive than the supporting electrolyte taking into account the $\mathrm{pH} 3$ of their suspensions. In change, steel corrosion was highly reduced in the corresponding tannate suspensions.

4. After $3 \mathrm{~h}$ of immersion, steel corrosion rate of all primed panels did not differ significantly from each other. At longer exposure times, the primer containing zinc tetroxychromate (ZTC) was the most effective in reducing the corrosion rate of steel.

5. Steel surface morphology was modified in Tara tannins (TT40 and TT80) suspensions. The oxide layer, partially destroyed by pitting, was replaced by a film which contained plates and powdery formations typical of tannins. Pits were not detected in the presence of 


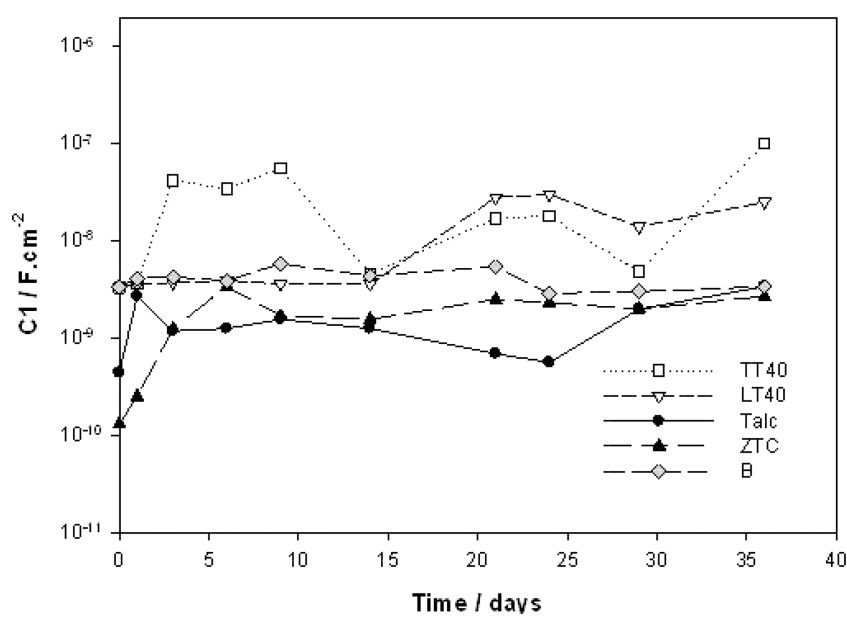

a

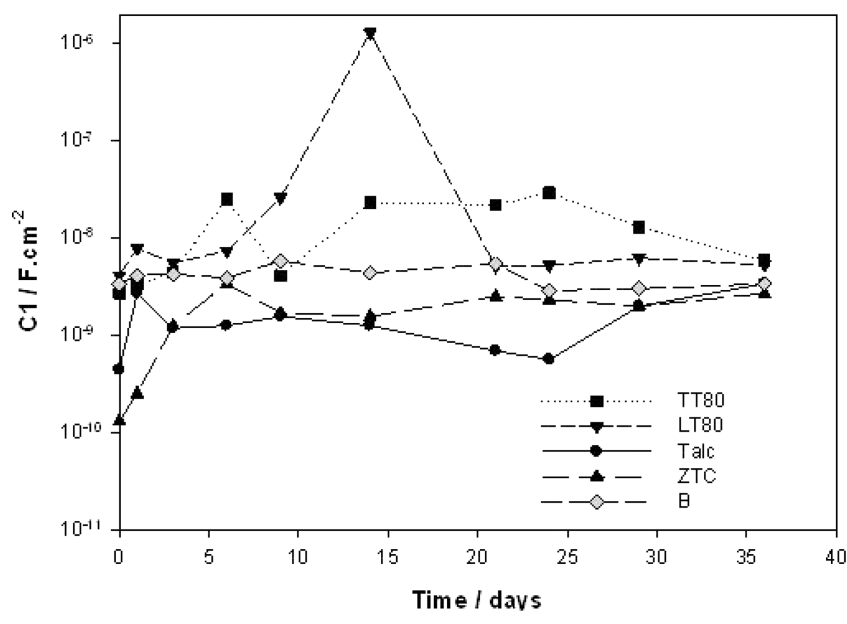

b

Figure 17. Coating capacitance of steel panels coated with the different painting schemes: (a) TT40 and its derivative LT40; (b) TT80 and its derivative LT80.

tannins. TT80 was less efficient than TT40 on protecting steel. The surface morphology in lanthanum tannate suspensions was also different and a very thin film covered the steel surface. The content of La on the surface was very high in the case of the steel panel in contact with the LT40 and this fact is responsible of its improved anticorrosion performance.

6. The anticorrosion performance of the primers improved when they were incorporated into a complete painting scheme.

7. Accelerated tests performed on painted panels revealed that at longer exposure time (90 days) the primer formulated with LT40 performed as the one containing ZTC. The primers formulated with both tannins exhibited a slightly worse behavior than those pigmented with LT40.

8. The highest value of the charge transfer resistance was obtained for the paint system containing the wash-primer pigmented with ZTC. However, the corrosion process was delayed for a long period in the case of the primer containing LT40. This fact points out that the primer pigmented with LT40 could be employed satisfactorily instead of that formulated with ZTC. The charge transfer

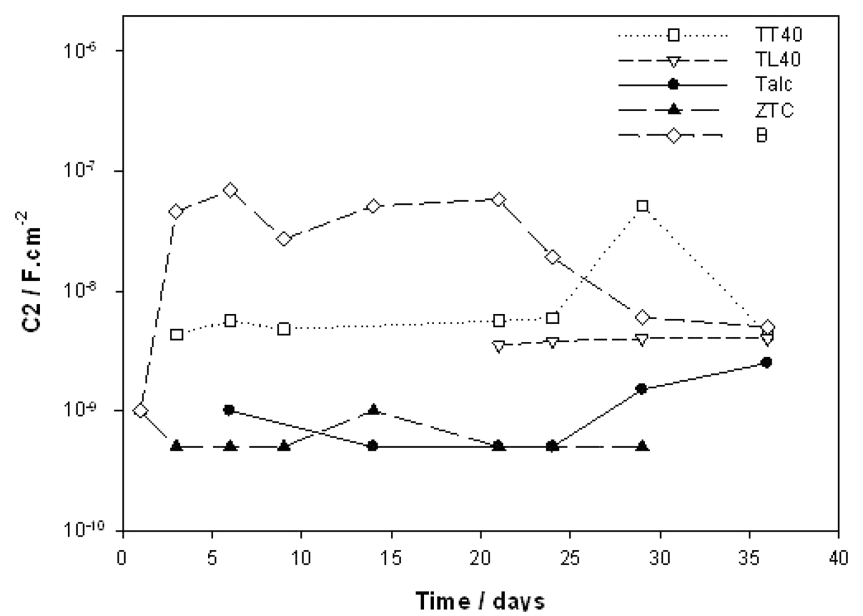

a

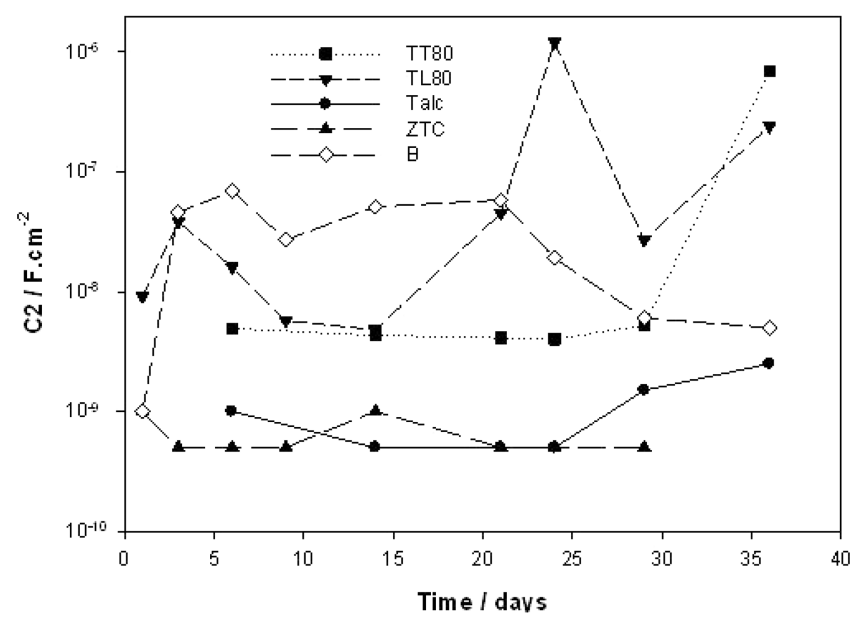

b

Figure 18. Double layer capacitance of steel panels coated with the different painting schemes: (a) TT40 and its derivative LT40; (b) TT80 and its derivative LT80.

resistance values of the rest of the primers suggest that they also could be employed as temporary corrosion protective coatings.

9. The presence of a wash-primer in the paint system reduced the electrochemical active area.

\section{ASSOCIATED CONTENT}

\section{Supporting Information}

The Supporting Information is available free of charge on the ACS Publications website at DOI: 10.1021/acs.iecr.7b03317.

Table S1: SAE 1010 steel corrosion rate in tannins and tannins derivatives suspensions in $0.10 \mathrm{M} \mathrm{NaCl}$. Table S2: Rusting degree (ASTM D610) of painted panels exposed in the salt spray chamber (ASTM B117). Table S3: Blistering degree (ASTM D714) of painted panels exposed in the humidity chamber (ASTM D2247). Figure S1: Polarization curves of "Tara” tannins (2 ppm) and lanthanum "tannates". The electrolyte used was 0.1 $\mathrm{M} \mathrm{NaCl}$, the scan rate was $0.5 \mathrm{mV} . \mathrm{s}^{-1}$ and the exposure time was 2 h. Figure S2: Experimental data and fitting curves of steel panel coated with the painting scheme containing the primer formulated with TT40 a) just after 
immersion (one time constant), b) after 78 days of immersion (two time constants) (PDF)

\section{AUTHOR INFORMATION}

\section{Corresponding Author}

*E-mail: c.deya@cidepint.gov.ar. ORCID ${ }^{\circ}$

Cecilia Deyá: 0000-0003-2853-5982

Notes

The authors declare no competing financial interest.

\section{ACKNOWLEDGMENTS}

We thank Universidad Nacional de La Plata (UNLP), Consejo Nacional de Investigaciones Científicas y Técnicas (CONICET), and Comisión de Investigaciones Científicas de Buenos Aires (CICPBA), for their support.

\section{REFERENCES}

(1) National Physical Laboratory. Guide to Temporary Corrosion Protectives. http://www.npl.co.uk/upload/pdf/temporary_corrosion protectives.pdf.

(2) Paul, S., Surface preparation and paint application. In Surface Coatings. Science and Technology, 2nd ed.; Paul, S., Ed.; John Wiley and Sons: England, 1996; pp 477-510.

(3) Waldie, J. M., Conversion coatings. In Surface Coatings: Paints and their Applications, Waldie, J. M., Ed.; England, 1984; Vol. II, pp 578588.

(4) Wilbur, S.; Abadin, H.; Fay, M. Health effects. In Toxicologycal Profile for Chromium; U.S. Department for Health and Human Services, Public Health Service, Agency for Toxic Substances and Disease Registry, 2012; pp 49-332.

(5) Cruz, B. H.; Díaz Cruz, J. M.; Ariño, C.; Esteban, M. Heavy metal binding by tannic acid, a voltammetric study. Electroanalysis 2000, 12 (14), 1130.

(6) Seavell, A. J. Anticorrosive properties of Mimosa (Wattle) tannin. J. Oil Col. Chem. Assoc. 1978, 61 (12), 439.

(7) Hornus Sack, S.; Romagnoli, R.; Vetere, V. F.; Elsner, C. I.; Pardini, O.; Almalvy, J. I.; Di Sarli, A. R. Evaluation of steel/primer based on chestnut tannin/paint film systems by EIS. J. Coat. Technol. 2002, 74 (926), 63.

(8) Martinez, S. Inhibitory mechanism of mimosa tannin using molecular modeling and substitutional adsorption isotherms. Mater. Chem. Phys. 2002, 77 (1), 97.

(9) Martinez, S.; Štern, I. Ferric-tannate formation and anticorrosive properties of mimosa tannin in acid solutions. Chem. Biochem. Eng. Q. 1999, 13 (4), 191.

(10) Martinez, S.; Štern, I. Inhibitory mechanism of low-carbon steel corrosion by mimosa tannin in sulphuric acid solutions. J. Appl. Electrochem. 2001, 31 (9), 973.

(11) Martinez, S.; Štern, I. Thermodynamic characterization of metal dissolution and inhibitor adsorption processes in the steel/mimosa tannin/sulfuric acid. Appl. Surf. Sci. 2002, 199 (1-4), 83.

(12) Pardini, O. R.; Amalvy, J. I.; Di Sarli, A. R.; Romagnoli, R.; Vetere, V. F. Formulation and testing of a water-borne primer containing chestnut tannin. J. Coat. Technol. 2001, 73 (913), 99.

(13) Matamala, G.; Smeltzer, W.; Droguett, G. Comparison of steel anticorrosive protection formulated with natural tannins extracted from acacia and from pine bark. Corros. Sci. 1994, 42 (8), 1351.

(14) Jaén, J.; Rodríguez, M. V. Application of Mössbauer spectroscopy to the study of tannins inhibition of iron and steel corrosion. Hyperfine Interact. 2011, 202 (1-3), 25.

(15) Rahim, A. A.; Rocca, E.; Steinmetz, J.; Jaim Kassim, M.; Adnan, R.; Sani Ibrahim, M. Mangrove tannins and their flavanoid monomers as alternative steel corrosion inhibitors in acidic medium. Corros. Sci. 2007, 49 (2), 402.
(16) Rahim, A. A.; Rocca, E.; Steinmetz, J.; Jain Kassim, M. Inhibitive action of mangrove tannins and phosphoric acid on pre-rusted steel via electrochemical methods. Corros. Sci. 2008, 50, 1546.

(17) López, A. J. A.; Jaén Jiménez, J. C.; Vargas Abarca, A. S.; Jiménez Bonilla, P.; Vega Guzmán, I.; Herrera Núñez, J.; Borbón Alpízar, H.; Soto Fallas, R. M. Extracción y evaluación de taninos condensados a partir de la corteza de once especies maderables de Costa Rica. Tecnología en Marcha 2012, 25 (4), 15.

(18) Chang, K.; Viswanathan, T. Electrochemical studies of tannin for corrosion protection of steel. Polymeric Materials: Science \& Engineering 2001, 84, 1055.

(19) González, M. I.; Abreu, A. Utilización de las curvas de polarización anódica para determinar la efectividad deun convertidor de óxidos. Revista de Ciencias Químicas de Cuba 1984, 15 (2), 315.

(20) Collazo, A.; Nóvoa, X. R.; Pérez, C.; Puga, B. EIS study of the rust converter effectiveness under different conditions. Electrochim. Acta 2008, 53 (25), 7565.

(21) Ocampo, L. M.; Margarit, I. C. P.; Mattos, O. R.; Córdoba-deTorresi, S. I.; Fragata, F. L. Performance of rust converter based in phosphoric and tannic acids. Corros. Sci. 2004, 46 (6), 1515.

(22) Giúdice, C. A.; Benítez, J. C.; Tonello, M. L. Tin tannates and iron tannates in corrosion-inhibiting coatings. Pitture e Vernici 1998, 74 (7), 23.

(23) Giúdice, C. A.; Benítez, J. C.; Tonello, M. L. Testing the use of metallic tannates as inhibitors in anticorrosive coatings. Protective Coatings Europe 1999, 4 (5), 13.

(24) Giúdice, C. A.; Benítez, J. C.; Tonello, M. L. Chromium (VI) tannates as inhibitors in anticorrosive coatings: influence of the metal content. European Coatings Journal 2000, 6, 48.

(25) Flores, S.; Caprari, J. J.; Figueroa, L.; Romagnoli, R. Inhibición De La Corrosión Del Acero Por "Tanatos" Metálicos. Estudio Comparativo De Pinturas Epoxídicas Formuladas Con Tanatos Metálicos En Ensayos De Corrosión Acelerada; Intercorr: 2014, Fortaleza, Brazil, 2014.

(26) Hadzich, A.; Flores, S.; Romagnoli, R.; Caprari, J. J. Estudios De Tanatos De Cinc Preparados Con Polvo De Tara (Caesalpinia Spinosa) Como Pigmentos Anticorrosivos En Pinturas Alquídicas Y Formulaciones De Wash Primers; X Latincorr: Mexico, 2016.

(27) Bellotti, N.; Deya, C.; del Amo, B.; Romagnoli, R. Antifouling Paints with Zinc "Tannate". Ind. Eng. Chem. Res. 2010, 49, 3386.

(28) Garro Gálvez, J. M.; Riedl, B.; Conner, A. H. Analytical studies on tara tannins. Holzforschung 1997, 51, 235.

(29) Giovando, S.; Pizzi, A.; Pasch, H.; Pretorius, N. Structure and Oligomers Distribution of Commercial Tara (Caesalpina spinosa) Hydrolysable Tannin. PRO LIGNO 2013, 9 (1), 22.

(30) Sanaei, Z.; Bahlakeh, G.; Ramezanzadeh, B. Active corrosion protection of mild steel by an epoxy ester coating reinforced with hybrid organic/inorganic green inhibitive pigment. J. Alloys Compd. 2017, 728, 1289.

(31) Umoren, S. A.; Solomon, M. M. Synergistic corrosion inhibition effect of metal cations and mixtures of organic compounds: A Review. J. Environ. Chem. Eng. 2017, 5, 246.

(32) Salehi, E.; Naderi, R.; Ramezanzadeh, B. Synthesis and characterization of an effective organic/inorganic hybrid green corrosion inhibitive complex based on zinc acetate/Urtica Dioica. Appl. Surf. Sci. 2017, 396, 1499.

(33) Prabakaran, M.; Ramesh, S.; Periasami, V. Synergistic effect of thiomalic acid and zinc ions in corrosion control of carbon steel in aqueous solution. Res. J. Chem. Sci. 2014, 4, 41.

(34) Carneiro, J.; Tedim, J.; Fernandesca, S. C. M.; Freire, C. S. R.; Silvestre, A. J. D.; Gandinia, A. Chitosan-based self-healing protective coatings dopped with cerium nitrate for corrosion protection of aluminium alloy 2024. Prog. Org. Coat. 2012, 75, 8.

(35) Coelho, L. B.; Mouanga, M.; Druart, M. E.; Recloux, I.; Cossement, D.; Olivier, M. G. A SVET study of the inhibitive effects of benzotriazole and cerium chloride solely and combined on an aluminium/copper galvanic coupling model. Corros. Sci. 2016, 110, 143. 
(36) Okeniyi, J. O.; Popoola, A. P. I.; Loto, C. A.; Omotosho, O. A.; Okpala, S. O.; Ambroe, I. J. Effect of $\mathrm{NaNO} 2$ and $\mathrm{C} 6 \mathrm{H} 15 \mathrm{NO} 3$ synergistic admixtures on steel-rebar corrosion in concrete immersed in aggressive environments. Adv. Mater. Sci. Eng. 2015, 2015, 1.

(37) Umoren, S. A.; Solomon, M. M. Effect of halide ions on the corrosion inhibition efficiency of different organic species: A Review. J. Ind. Eng. Chem. 2015, 21, 81.

(38) Davó, B.; de Damborenea, J. J. Use of rare earth salts as electrochemical corrosion inhibitors for an $\mathrm{Al}-\mathrm{Li}-\mathrm{Cu}$ (8090) alloy in 3.56\% NaC. Electrochim. Acta 2004, 49 (27), 4957.

(39) Forsyth, M.; Wilson, K.; Behrsing, T.; Forsyth, C.; Deacon, G. B.; Phanasgoankar, A. Effectiveness of rare-earth metal compoundsas corrosion inhibitors for steel. Corrosion (Houston, TX, U. S.) 2002, 58 (11), 953.

(40) Erdemoğlu, S. B.; Gücer, S. Selective determination of aluminium bound with tannin in tea infusion. Anal. Sci. 2005, 21, 1005.

(41) Ferreira, E.; Nogueira, A. R. A.; Souza, G. B.; Batista, L. A. R. Effect of drying method and length of storage on tannin and total phenol concentrations in pigeon pea seeds. Food Chem. 2004, 86, 17.

(42) Rosynek, M. P.; Magnuson, D. T. Preparation and characterization of catalytic lanthanum oxide. J. Catal. 1977, 46 (3), 402.

(43) Rodríguez Gómez, F. J., Técnicas electroquímicas de corriente directa para la medición de la velocidad de corrosion. Resistencia a la polarización. In Técnicas Electroquimicas Para El Estudio De La Corrosion; LLongueras, J. G., Ed.; Laboratorio de Corrosión de la Facultad de Química de la UNAM: México, 1989; pp 1-9.

(44) Wolynec, S., Determinação da taxa de corrosão e de outros parâmetros. In Técnicas eletroquimicas en corroção, Wolynec, S., Ed.; Ed.a da Universidade de São Paulo: São Paulo, 2003; pp 95-114.

(45) Rosenbloom, H. Chemistry of Wash Primers. Ind. Eng. Chem. 1953, 45, (11).256110.1021/ie50527a052

(46) Butvar. Polyvinyl butiral resin. Properties and uses Publication $\mathrm{N}^{\circ}$ 2008084E, Coatings performance materials by SOLUTIA. http:// www.butvar.com.

(47) Asbeck, W. K.; Loo, M. V. Critical Pigment Volume Relationships. Ind. Eng. Chem. 1949, 41 (7), 1470.

(48) Hare, C. Protective Coatings. Fundamentals of Chemistry and composition; Technology Publishing Company: PA, 1994.

(49) Koleske, J. Paint and coating testing manual. In Gardner-Sward Handbook, 14th ed.; ASTM: PA, 1995.

(50) Walter, G. W. A review of impedance plot methods used for corrosion performance analysis of painted metals. Corros. Sci. 1986, 26 (9), 681

(51) Bittner, A. Advanced phosphate anticorrosive pigments for compliant primers. J. Coat. Technol. 1989, 61 (777), 118.

(52) Gerhard, A.; Bittner, A. Second generation phosphate anticorrosive pigments. Formulating rules for full replacement of new anticorrosive pigments. J. Coat. Technol. 1986, 58 (740), 59.

(53) Boukamp, B. A. Equivalent Circuit; University of Twente: The Netherlands, 1989.

(54) D’Alessandro, O.; Selmi, G. J.; Deyá, C.; Di Sarli, A. R.; Romagnoli, R. Formulation and assessment of a wash-primer containing lanthanum "tannate" for steel temporary protection. J. Mater. Eng. Perform. 2018, doi.org/10.1007/s11665-017-3103y.2768710.1007/s11665-017-3103-y

(55) Grasel, F. d. S.; Ferrão, M. F.; Wolf, C. R. Development of methodology for identification the nature of the polyphenolic extracts by FTIR associated with multivariate analysis. Spectrochim. Acta, Part A 2016, 153, (Supplement C).9410.1016/j.saa.2015.08.020

(56) Colthup, N.; Daly, L.; Wiberley, S. Major spectra-structure correlations by spectral regions. In Introduction to Infrared and Raman Spectroscopy, Introduction to Infrared and Raman Spectroscopy, 3rd ed.; Academic Press: UK, 1990; pp 387-482.

(57) Silverstein, R. M.; Webster, F. X.; Kiemle, D. J.; Bryce, D. L., Infrared Spectroscopy. In Spectrometric Identification of Organic Compounds. 8th ed. ed.; Wiley: USA, 2015.

(58) Kendig, M.; Scully, J. Basic aspects of electrochemical impedance, application for the life prediction of organic coatings on metals. Corrosion 1990, 46, 22.
(59) Mansfeld, F. Recording and analysis of AC impedance data for corrosion studies. Background and methods of analysis. Corrosion 1981, 36 (5), 301.

(60) Szauer, T. Impedance measurements for the evaluation of protective nonmetallic coatings. Prog. Org. Coat. 1982, 2 (10), 171.

(61) Vetere, V. F.; Romagnoli, R. Chemical and electrochemical assessment of tannins and aqueous primers containing tannins. Surf. Coat. Int. 1998, 81 (8), 385.

(62) Amirudin, A.; Thierry, D. Application ef Electrochemica Impedance Spectroscopy to study efficiency of anticorrosive pigment in epoxy-polyamide resin. Br. Corros. J. 1995, 30 (2), 128.

(63) Skale, S.; Doleček, V.; Slemnik, M. Electrochemical impedance studies of corrosion protected surfaces covered with epoxy polyamide coating system. Prog. Org. Coat. 2008, 62, 387.

(64) van Westing, E. P. M.; Ferrari, G. M.; Geenen, F. M.; de Wit, J. $\mathrm{H}$. W. In situ determination of the loss of adhesion of barrier epoxy coatings using electrochemical impedance spectroscopy. Prog. Org. Coat. 1993, 23, (1).8910.1016/0033-0655(93)80006-V

(65) Szauer, T. Electrical and electrochemical resistance for protective non metallic coatings. Prog. Org. Coat. 1982, 10, 157.

(66) Leidheiser, H. Electrical and electrochemical measurements as predictors of corrosion at the metal-organic coatings interface. Prog. Org. Coat. 1979, 7, 70. 